\title{
Study of the effects of process parameters on tool wear rate in powder mixed electrical discharge machining by Taguchi method
}

\author{
Phan - Nguyen Huu
}

\begin{abstract}
There have been various attempts to improve the surface finish after Electrical Discharge Machining (EDM) by polishing and other means. But if it is possible to improve the surface during machining it will shorten the machining time. From this viewpoint powder mixed EDM (PMEDM) is one of these processes. PMEDM not only imparts fine machined surface finish but also modifies the machined surface. However, it is necessary to understand the mechanism of PMEDM process. In this study, influence of process parameters to tool wear rate (TWR) of PMEDM using titanium (Ti) powder is presented. The objective of the study is to evaluate the main effects of workpiece material, tool material, polarity, pulse-on time, intensity of discharge, pulse-off time, and powder concentration on the TWR in PMEDM. They carried out the investigation based on the Taguchi method involving seven control factors with three levels for an orthogonal array L27 (1313).The results indicated that electrode material, electrode polarity, pulse on time, current and powder concentration were the most significant parameters that influenced the TWR. This result will be the basis for selecting the factors in further optimization studies.
\end{abstract}

Index Terms - TWR; EDM; PMEDM; Taguchi method.

\section{INTRODUCTION}

EDM is a non traditional machining process that has become a well established machining option in manufacturing industries throughout the

Manuscript Received on April 11th, 2017, Manuscript Revised November 14th, 2016

Phan - Nguyen Huu - Faculty of Mechanical Engineering, Hanoi University of Industry, Ha Noi, Vietnam (e-mail: phanktcn@gmail.com). world and has replaced drilling, milling, grinding and other traditional machining operations. With the continuous process improvement in EDM, the demand for high machining precision with low surface roughness at relatively high machining rates arise in die, mold and tool manufacturing industries. To fulfill this requirement a relatively new advancement in the direction of process capabilities is the addition of powder in the dielectric fluid of EDM. The results show that PMEDM can distinctly improve the surface finish and surface quality.

Past research into PMEDM methods have proven promising as methods to improve both the productivity and quality in EDM. Prior research has shown that, a suitable powder is mixed into the dielectric fluid used in EDM, which can lead to both an increased material removal rate (MRR) and TWR is reduced. Increasing the concentration of powder 2-6 g/l can lead to an increased MRR, while concurrently reducing the TWR [1]. Graphite powder mixed in the dielectric fluid can be beneficial to the influence of EDM and has decreased the TWR by $28 \%$ [2]. When Si powder is mixed into the dielectric fluid, there is a strong increase in MRR, further roughing the EDM $[3,4]$. However, the TWR and chip mixed with powder have still not been addressed. Taguchi method has been widely used to optimize quality characteristics in the field of EDM [5-8]. The effect of current, pulse-on time, and pulse-off time on the TWR of the copper electrode during machining of EN31 was assessed using the Taguchi method $[9,10]$. The results showed that using powder reduces the TWR. Conversely, an increase in current and pulse on time increased the TWR. Three different powder materials were used, 
namely $\mathrm{Gr}, \mathrm{SiC}$, and $\mathrm{Al}_{2} \mathrm{O}_{3}$ powders, in the dielectric media $[11,12]$. The Gr powder helped to increase the MRR, while $\mathrm{SiC}$ powder helped to reduce the TWR. Many researchers used metal powder in the kerosene dielectric fluid and investigated the various effects on the machining parameters such as surface roughness, TWR, material removal rate. From the literature survey, it is observed that the improvement of EDM efficiency by PMEDM is still at the experimental stage.

The intent of the present study is to study the effect of different input parameters, namely, workpiece material, tool material, polarity, pulseon time, current, pulse-off time, and powder concentration and some their interactions on the TWR in PMEDM using Ti powder. The effect of various input parameters on output response have been analyzed using Analysis of Variance (ANOVA). Main effect plot and interaction plot for significant factors have been used to determine the optimal design for TWR.

\section{EXPERIMENTAL PROCEDURE}

\subsection{Experimental Equipment}

An electrical discharge machine, AG40L (Sodick, Inc. USA), was used. A schematic experiment is shown in Figure 1. The tank was made of CT3 steel with size 330x180x320 mm and motor shafts were fitted by stirring at $100 \mathrm{rev} / \mathrm{min}$ with Ti powder and were mixed with the dielectric fluid (oil HD-1) during the experiment (see also Figure 1). The workpiece materials included SKD61, SKD11, and SKT4 mould steels, where the common type used in industry standards were selected for this study. Samples measured $45 \times 27 \times 10 \mathrm{~mm}$. Furthermore, $\mathrm{Cu}, \mathrm{Gr}$ are among the two materials most commonly used, and have been a focus of recent research. The electrode was shaped into a circular cylinder and it had a diameter measuring $23 \mathrm{~mm}$. The powder material chosen for this study was titanium (Ti) of $45 \mu \mathrm{m}$ grain size. The mass before and after processing was measured with an electronic scale AJ 203 (Shinko Denshi Co. LTD - Japan), with the largest mass measured of $200 \mathrm{~g}$, and an accuracy of $0.001 \mathrm{~g}$.

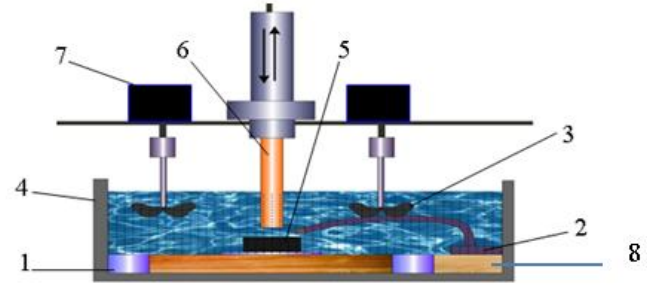

1- Magnets 2-Pump 3-Nozzle 4- Machining tank 5 -Workpiece 6- electrode 7-Stirring 8-Wood panels Figure 1. Schematic line diagram.

\subsection{Experimental Methods}

The Taguchi method is used to design experiments based on the orthogonal matrix, and is used to assess the process parameters. This method included a simple experimental design and standardization. The experimental design of Taguchi method was implemented by the orthogonal matrix (table 2) for placement of the technological parameters, which were examined by their levels with the smallest number of experiments during the time as well as the least expensive. The selection of tables was based on the number of parameters and their change rates. ANOVA was based on data obtained from Taguchi's experimental design and was used to select new parameter values to optimize the quality characteristics. Data from the table was analyzed by using charts, pictures, ANOVA and the Fisher ratio test $(\mathrm{F})$.

$F$ value is defined as:

$$
\begin{aligned}
& \mathrm{F}=\frac{\text { MSfor a term }}{\text { MSfor the error term }} \\
& \text { MS }- \text { Mean Square for a term. } \\
& \text { MS - Mean Square for the error a term. }
\end{aligned}
$$

The Sum of Squares (SS) is a measure of the deviation of the experimental data from the mean value of the data.

$$
\mathrm{SS}=\sum_{\mathrm{i}=1}^{\mathrm{N}}\left(\mathrm{y}_{\mathrm{i}}-\bar{\gamma}\right)^{2}
$$

$\mathrm{N}$ - number of response observations.

$y_{i}-$ the $\mathrm{i}^{\text {th }}$ response.

$\bar{\gamma}-$ the mean of all observations. 
Table 1. Input parameters and its levels.

\begin{tabular}{|c|c|c|c|c|c|c|}
\hline \multirow[t]{2}{*}{ No } & \multirow[b]{2}{*}{ Factors } & \multirow[b]{2}{*}{ Symbols } & \multicolumn{3}{|c|}{ Level } & \multirow[b]{2}{*}{$\begin{array}{c}\text { DO } \\
\text { F }\end{array}$} \\
\hline & & & Level 1 & $\begin{array}{c}\text { Level } \\
2\end{array}$ & $\begin{array}{c}\text { Level } \\
3\end{array}$ & \\
\hline 1 & Workpiece material & $\mathrm{A}$ & SKD61 & $\begin{array}{c}\text { SKD } \\
11\end{array}$ & $\begin{array}{c}\text { SKT } \\
4\end{array}$ & 2 \\
\hline 2 & Electrode material & $\mathrm{B}$ & $\mathrm{Cu}$ & $\mathrm{Cu}^{\mathrm{a}}$ & Gr & 1 \\
\hline 3 & Polarity & $\mathrm{C}$ & - & + & $-^{\mathrm{a}}$ & 1 \\
\hline 4 & Pulse-on time ( $\mu \mathrm{s})$ & $\mathrm{D}$ & 5 & 10 & 20 & 2 \\
\hline 5 & Current (A) & $\mathrm{E}$ & 8 & 4 & 6 & 2 \\
\hline 6 & Pulse-off time ( $\mu \mathrm{s})$ & $\mathrm{F}$ & 38 & 57 & 85 & 2 \\
\hline 7 & $\begin{array}{l}\text { Powder } \\
\text { concentrationTi }(\mathrm{g} / \mathrm{l})\end{array}$ & $\mathrm{G}$ & 0 & 10 & 20 & 2 \\
\hline 8 & $\begin{array}{l}\text { Interaction of } \\
\text { workpiece material } \\
\text { and tool material }\end{array}$ & $\mathrm{A} \times \mathrm{B}$ & - & - & - & 2 \\
\hline 9 & $\begin{array}{l}\text { Interaction of } \\
\text { workpiece material } \\
\text { and powder } \\
\text { concentration }\end{array}$ & $\mathrm{A} \times \mathrm{G}$ & - & - & - & 4 \\
\hline 10 & $\begin{array}{l}\text { Interaction of tool } \\
\text { material and powder } \\
\text { concentration }\end{array}$ & $\mathrm{B} \times \mathrm{G}$ & - & - & - & 2 \\
\hline & & Total & & & & 20 \\
\hline
\end{tabular}

\section{a- Dummy treated}

In the current study, the interaction effect of the input parameters was considered, as shown in Table 1. In the field of PMEDM, researchers have studied the effect of powder size, workpiece material, electrode material, current, pulse-on time, and pulse-off time. In this study, the interaction terms were considered, specifically workpiece material, $\mathrm{x}$-electrode material $(\mathrm{AxB})$, workpiece material, $x$-powder concentration $(A x G)$, and electrode material $\mathrm{x}$-powder concentration $(\mathrm{BxG})$. The reason why these seven factors have been chosen is that they are the most general and frequently used by EDM researchers.

Taguchi's orthogonal array's was used for designing the experiments. There are many orthogonal array's available in the Taguchi's method, therefore selection depended upon the number of factors and degrees of freedom of each factor. In this study, seven main factors were considered, out of which, two factors were at two levels, each having one degree of freedom. Five of the main factors had three levels, with each having two degrees of freedom. Also, the study considered three interaction terms. Thus, the total sum of degrees of freedom, including the main factors as well as the interaction terms, was 20 . Therefore, based on the 20 degrees of freedom, the L27 orthogonal array suited the present requirements as it had 26 degrees of freedom. The remaining 6 degrees of freedom were assigned as random error. The L27 orthogonal array had 13 columns, each with 2 degrees of freedom [13]. Coefficient A was assigned to the column 1, B to column 2, G to column 5, C to column 9, D to column 10, E to column 12, and F to column 13, as shown in Table 2.

\section{RESULTS AND DISCUSSION.}

\subsection{Result of experiments}

The results for TWR for each of the 27 treatment conditions with repetition are given in Table 2 . TWR of the electrode was measured by dividing the weight of the electrode before and after machining against the machining time achieved. Equation 3 was used to determine the TWR value:

$$
\mathrm{TWR}=\frac{\mathrm{T}_{\mathrm{i}}-\mathrm{T}_{\mathrm{f}}}{\rho_{\mathrm{T}} \mathrm{t}} \cdot 1000 \mathrm{~mm}^{3} / \mathrm{min}
$$

Where

$\mathrm{T}_{\mathrm{i}}$ - Initial weight of tool electrode $(\mathrm{g})$

$\mathrm{T}_{\mathrm{f}}-$ Final weight of tool electrode $(\mathrm{g})$

$\mathrm{t}$ - Time period of trails in minutes $(\mathrm{t}=20 \mathrm{~min})$

$\rho_{\mathrm{T}}-$ Density of tool electrode $\left(\rho_{\mathrm{T}}=8.94 \mathrm{~g} / \mathrm{cc}\right)$

Each experiment was repeated three times, and Minitab software was used to analyze the experimental results. The results were processed by Minitab 16 to determine the mean value of the machining characteristics as well as the coefficient, S/N. The results are given in table 2 .

Table 2. L27 orthogonal array and results of experiments.

\begin{tabular}{|c|c|c|c|c|c|c|c|c|}
\hline $\begin{array}{c}\text { Exp. } \\
\text { No }\end{array}$ & $\begin{array}{c}\text { Workpiece } \\
\text { material }\end{array}$ & $\begin{array}{c}\text { Electrode } \\
\text { material }\end{array}$ & $\begin{array}{l}\text { Electrode } \\
\text { polarity }\end{array}$ & $\begin{array}{l}\text { Pulse on } \\
\text { Time }(\mu \mathrm{s})\end{array}$ & $\begin{array}{c}\text { Pulse } \\
\text { Current (A) }\end{array}$ & $\begin{array}{c}\text { Pulse of } \\
\text { Time }(\mu \mathrm{s})\end{array}$ & $\begin{array}{c}\text { Powder } \\
\text { Concentration }(\mathrm{g} / \mathrm{l})\end{array}$ & $\overline{T W R}$ \\
\hline 1 & SKD61 & $\mathrm{Cu}$ & - & 5 & 8 & 38 & 0 & 1.95 \\
\hline 2 & SKD61 & $\mathrm{Cu}$ & + & 10 & 4 & 57 & 10 & 2.011 \\
\hline 3 & SKD61 & $\mathrm{Cu}$ & $-^{\mathrm{a}}$ & 20 & 6 & 85 & 20 & 1.495 \\
\hline 4 & SKD61 & $\mathrm{Cu}^{\mathrm{a}}$ & + & 10 & 6 & 85 & 0 & 4.426 \\
\hline 5 & SKD61 & $\mathrm{Cu}^{\mathrm{a}}$ & $-^{\mathrm{a}}$ & 20 & 8 & 38 & 10 & 4.364 \\
\hline
\end{tabular}




\begin{tabular}{|c|c|c|c|c|c|c|c|c|}
\hline 6 & SKD61 & $\mathrm{Cu}^{\mathrm{a}}$ & - & 5 & 4 & 57 & 20 & 0.054 \\
\hline 7 & SKD61 & $\mathrm{Gr}$ & $-^{a}$ & 20 & 4 & 57 & 0 & 11.499 \\
\hline 8 & SKD61 & $\mathrm{Gr}$ & - & 5 & 6 & 85 & 10 & 9.935 \\
\hline 9 & SKD61 & $\mathrm{Gr}$ & + & 10 & 8 & 38 & 20 & 19.626 \\
\hline 10 & SKD11 & $\mathrm{Cu}$ & + & 20 & 4 & 85 & 0 & 2.01 \\
\hline 11 & SKD11 & $\mathrm{Cu}$ & $-^{\mathrm{a}}$ & 5 & 6 & 38 & 10 & 1.179 \\
\hline 12 & SKD11 & $\mathrm{Cu}$ & - & 10 & 8 & 57 & 20 & 3.56 \\
\hline 13 & SKD11 & $\mathrm{Cu}^{\mathrm{a}}$ & $-^{\mathrm{a}}$ & 5 & 8 & 57 & 0 & 2.25 \\
\hline 14 & SKD11 & $\mathrm{Cu}^{\mathrm{a}}$ & - & 10 & 4 & 85 & 10 & 0.132 \\
\hline 15 & SKD11 & $\mathrm{Cu}^{\mathrm{a}}$ & + & 20 & 6 & 38 & 20 & 1.495 \\
\hline 16 & SKD11 & $\mathrm{Gr}$ & - & 10 & 6 & 38 & 0 & 7.439 \\
\hline 17 & SKD11 & $\mathrm{Gr}$ & + & 20 & 8 & 57 & 10 & 14.073 \\
\hline 18 & SKD11 & $\mathrm{Gr}$ & $-^{\mathrm{a}}$ & 5 & 4 & 85 & 20 & 5.491 \\
\hline 19 & SKT4 & $\mathrm{Cu}$ & $-^{\mathrm{a}}$ & 10 & 6 & 57 & 0 & 0.587 \\
\hline 20 & SKT4 & $\mathrm{Cu}$ & - & 20 & 8 & 85 & 10 & 5.078 \\
\hline 21 & SKT4 & $\mathrm{Cu}$ & + & 5 & 4 & 38 & 20 & 2.902 \\
\hline 22 & SKT4 & $\mathrm{Cu}^{\mathrm{a}}$ & - & 20 & 4 & 38 & 0 & 0.277 \\
\hline 23 & SKT4 & $\mathrm{Cu}^{\mathrm{a}}$ & + & 5 & 6 & 57 & 10 & 4.715 \\
\hline 24 & SKT4 & $\mathrm{Cu}^{\mathrm{a}}$ & $-^{\mathrm{a}}$ & 10 & 8 & 85 & 20 & 4.413 \\
\hline 25 & SKT4 & $\mathrm{Gr}$ & + & 5 & 8 & 85 & 0 & 4.537 \\
\hline 26 & SKT4 & $\mathrm{Gr}$ & $-^{\mathrm{a}}$ & 10 & 4 & 38 & 10 & 9.041 \\
\hline 27 & SKT4 & $\mathrm{Gr}$ & - & 20 & 6 & 57 & 20 & 14.581 \\
\hline
\end{tabular}

\section{a- Dummy treated.}

\subsection{Effect of factors on TWR}

The results for TWR were analyzed using ANOVA for identifying the significant factors affecting the performance measures. ANOVA for the mean TWR at $99 \%$ confidence interval is given in Table 3. The variance data for each factor and their interactions were F-tested to find the significance of each. ANOVA table shows that workpiece material (F value 16.15), electrode material ( $\mathrm{F}$ value 453.41), pulse on time ( $\mathrm{F}$ value 16.69), current (F value 21.27), powder concentration (F value 19.68), $\mathrm{AxB}$ ( $\mathrm{F}$ value 15.12), BxG (F value 13.78) factors that affect the TWR. All remaining factors and the interactions are insignificant to affect TWR. It is observed that the electrode material is the most significant factor which contributes TWR. Main effects plot for TWR are shown in the Figure 2 that shows TWR increases with increase in current from 4 Amp to 8 Amp and also increases with increase in pulse on time from $5 \mu$ s to $20 \mu \mathrm{s}$. Electrode wear in copper electrode as comparison to graphite electrode is much less. TWR increases with powder mixing in dielectric. TWR is the smallest with SKD11 and pulse off time $85 \mu \mathrm{s}$, and it is the largest with SKD61 and pulse off time $38 \mu \mathrm{s}$. The interaction plots are shown in the Figure 3 which shows the interaction of electrode material $x$ powder concentration and interaction of electrode material $\mathrm{x}$ workpiece material is significant for the TWR. Table 4 shows ranks to various factors; electrode material has highest rank, most significant that affecting TWR. The electrode polarity and pulse off time are least significant in TWR.

Table 3. ANOVA of TWR

\begin{tabular}{|l|c|r|r|c|}
\hline \multicolumn{1}{|c|}{ Source } & DOF & \multicolumn{1}{c|}{ SS } & \multicolumn{1}{c|}{ V } & F \\
\hline Workpiece material (A) & 2 & 17.476 & 8.738 & 16.15 \\
\hline Electrode material (B) & 1 & 414.147 & 414.147 & 453.41 \\
\hline Electrode polarity (C) & 1 & 14.79 & 14.79 & - \\
\hline Pulse on time (D) & 2 & 30.487 & 15.243 & 16.69 \\
\hline Current (E) & 2 & 38.871 & 19.435 & 21.27 \\
\hline Pulse off time (F) & 2 & 14.496 & 7.248 & - \\
\hline $\begin{array}{l}\text { Powder concentration } \\
(\mathrm{G})\end{array}$ & 2 & 22.19 & 17.983 & 19.68 \\
\hline A $\times \mathrm{B}$ & 2 & 27.626 & 13.183 & 15.12 \\
\hline A $\times \mathrm{G}$ & 4 & 37.514 & 9.378 & - \\
\hline $\mathrm{B} \times \mathrm{G}$ & 2 & 25.174 & 21.618 & 13.78 \\
\hline Error & 6 & 5.481 & 0.937 & - \\
\hline Total & 26 & 648.238 & - & - \\
\hline $\mathrm{e}-\mathrm{pooled}$ & 11 & 5.481 & 0.910 & - \\
\hline
\end{tabular}




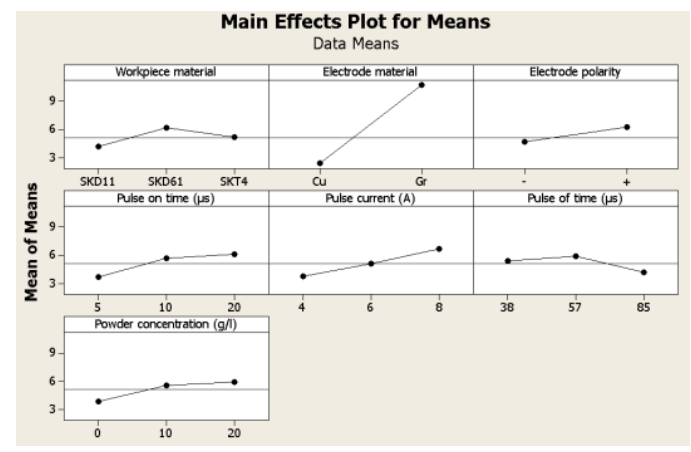

Figure 2. Main effects plot for TWR.

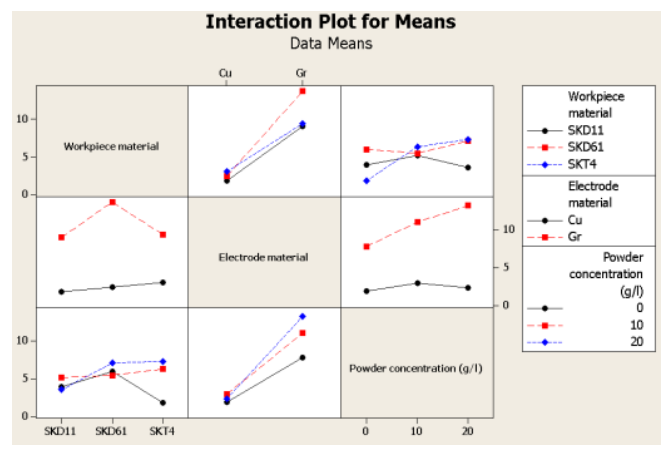

Figure 3. Interaction plot for TWR.

Table 4. Response table for a mean of TWR.

\begin{tabular}{|c|c|c|c|c|c|c|c|}
\hline \multirow{2}{*}{ Level } & \multicolumn{7}{|c|}{ Input parameters } \\
\cline { 2 - 8 } & $\mathrm{A}$ & $\mathrm{B}$ & $\mathrm{C}$ & $\mathrm{D}$ & $\mathrm{E}$ & $\mathrm{F}$ & $\mathrm{G}$ \\
\hline 1 & 4.181 & 2.383 & 4.629 & 3.668 & 3.713 & 5.364 & 5.958 \\
\hline 2 & 6.151 & 10.691 & 6.199 & 5.693 & 5.095 & 5.926 & 3.886 \\
\hline 3 & 5.126 & - & - & 6.097 & 6.65 & 4.168 & 5.614 \\
\hline Delta & 1.970 & 8.308 & 1.570 & 2.429 & 2.937 & 1.757 & 2.072 \\
\hline Rank & 5 & 1 & 7 & 3 & 2 & 6 & 4 \\
\hline
\end{tabular}

\section{Conclusion.}

The effect of parameters i.e. workpiece material, electrode material, electrode polarity, pulse on time, pulse off time, current, powder concentration and some of their interactions were evaluated using ANOVA and factorial design analysis. The purpose of the ANOVA was to identify the important parameters in prediction TWR. Some results consolidated from ANOVA and plots are given below: workpiece material, electrode material, and pulse on time, current, powder concentration were the significant factors which affects the TWR. Factors, namely, electrode polarity and pulse off time were found to be insignificant for TWR. And the effect of electrode material is the largest (63.75\% of total effect). TWR of $\mathrm{Cu}$ is smaller than its Gr. TWR is less varied in PMEDM with SKD11, SKD61 and SKT4 steels. TWR is smallest with $\mathrm{Cu}$ electrode and SKD11 steel.

Only three workpiece materials, namely, SKD61, SKD11 and SKT4 had been used. Other materials such as Ti, OHNS die steel and tungsten hot work die steel can be machined. Machining was carried out only with titan powder $(\approx 45 \mu \mathrm{m})$. Other powders, namely, silicon, nickel, vanadium, graphite, and aluminum can be used. Particle size and powder concentration can also be varied.

\section{REFERENCES}

[1] K. Ojha, R. K. Garg, K. K. Singh, "Experimental Investigation and Modeling of PMEDM Process with Chromium Powder Suspended Dielectric", International Journal of Applied Science and Engineering, vol. 9, no. 2, pp. 65-81, 2011.

[2] M. L. Jeswani, "Effect of the addition of graphite powder to kerosene used as the dielectric fluid in electrical discharge machining", Wear, vol. 70, no. 2, pp.133-139, 1981.

[3] P. Pec,as, E. Henriques, "Influence of silicon powdermixed dielectric on conventional electrical discharge machining", International Journal of Machine Tools \& Manufacture, vol. 43, no. 14, pp.1465-1471, 2003.

[4] W.S. Zhao, Q.G.Meng, Z.L.Wang, "The application of research on powder mixed EDM in rough machining", Journal of materials processing technology, vol. 129, no, 1-3, pp.30-33, 2002.

[5] B. Özerkan, C. Çogun, "Effect of mixed dielectric on machining performance in electric discharge machining", Gazi University Journal of Science, vol. 18, no. 2, pp.211-228, 2005.

[6] P. Singh, A. L. Kumar, N. Beri, V.Kumar, "Influence of electrical parameters in Powder mixed electric discharge machining (pmedm) of hastelloy", Journal of Engineering Research and Studies, 1, pp.93105, 2010. 
[7] H.K. Kansal, S. Singh, P. Kumar, "Effect of Silicon Powder Mixed EDM on Machining Rate of AISI D2 Die Steel", Journal of Manufacturing Processes, vol. 9, no. 1, pp. 13-22, 2007.

[8] C. R. Dr. Sanghani,G. D. Acharya, "A Review of Research on Improvement and Optimization of Performance Measures for Electrical Discharge Machining", Int. Journal of Engineering Research and Applications, vol. 4, no. 1, pp. 433-450, 2014.

[9] V. Parkash, D. Kumar, "Effect of Powder Mixed Dielectric Medium on Tool Wear Rate in EDM", International journal of scientific research (IJSR), vol. 2, no. 2, pp.107-109, 2013.

[10] G. Singh, P. Singh, G. Tejpal, B. Singh, "Effect of machining parameters on surface roughness of $\mathrm{H} 13$ Steel in EDM process using powder mixed fluid", International Journal of Advanced Engineering Research and Studies, vol. 2, no. 1, pp.148150, 2012.

[11] M. A. Razak, A. M. Abdul-Rani, and A. M Nanimina, "Improving EDM Efficiency with Silicon Carbide Powder-Mixed Dielectric Fluid", International Journal of Materials, Mechanics and Manufacturing, vol. 3, no. 1, pp.40-43, 2015.

[12] M. G. Rathi, D. V. Mane, "Study on Effect of Powder Mixed dielectric in EDM of Inconel 718", International Journal of Scientific and Research Publications, vol. 4, no. 11, pp.1-7, 2014

[13] R. Roy, A Primer on the Taguchi Method, New York: Van Nostrand Reinhold, 1990.

Phan Nguyen Huu is a lecture, Faculty of Mechanical Engineering, Hanoi University of Industry, Ha Noi, Vietnam (e-mail: phanktcn@gmail.com).

\title{
Nghiên cứu ảnh hưởng của các thông số đến lượng mòn điện cực trong gia công bằng tia lửa điện có bột trộn trong dung dịch điện môi bằng phương pháp Taguchi
}

\author{
Nguyễn Hữu Phấn
}

Tóm tắt-Bề mặt sau gia công bằng tia lửa điện $(\mathrm{EDM})$ đã và đang được cải thiện bằng nhiều biện pháp như: đánh bóng và một số phương pháp khác. Nhưng nếu có thể cải thiện bề mặt gia công ngay trong quá trình gia công, nó sẽ làm giảm thời gian gia công. Các kết quả nghiên cứu gần đây đã cho thấy, PMEDM là một trong những biện pháp công nghệ có thể cải thiện được chất lượng lớp bề mặt gia công. Tuy nhiên, nó là cần thiết để hiểu rõ về cơ chế gia công của PMEDM. Trong nghiên cứu này, ảnh hưởng của các thông số công nghệ đến lượng mòn điện cực (TWR) của PMEDM sử dụng bột Titan đã được chỉ ra. Ảnh hưởng của các thông số: vật liệu điện cực, vật liệu phôi, sự phân cực điện cực, thời gian phát xung, thời gian ngừng phát xung, cường độ dòng điện và nồng độ bột titan đến TWR của PMEDM được xem xét. Phương pháp Taguchi được sử dụng dụng để đánh giá ảnh hưởng của 7 thông số công nghệ với 3 mức bằng ma trận thí nghiệm L27 (1313). Kết quả cho thấy: vật liệu điện cực, sự phân cực điện cực, thời gian phát xung, cường độ dòng điện và nồng độ bột là những thông số có ảnh hưởng mạnh đến TWR. Kết quả nghiên cứu sẽ là cơ sở để lựa chọn các hệ số đưa vào trong các mô hình nghiên cứu tối ưu tiếp theo.

Tù khóa-TWR; EDM; PMEDM; phương pháp Taguchi. 